ISSN No. 0974-035X

An Indexed, Refereed \& Peer Reviewed Journal of Higher Education

\title{
THE IMPACT OF INTELLIGENCE AND APTITUDE IN THE SECOND LANGUAGE LEARNING: A BRIEF STUDY
}

\section{Hitendra Vyas}

\section{Abstract:}

This paper focuses on the relationship between Intelligence and Aptitude, and second language learning. The definition of aptitude refers to cognitive abilities rather than attitudes and affective dimensions of learning. Aptitude measures can predict achievement in cognitive language capacity rather than ability to communicate on an interpersonal level.

Two sets of intellectual abilities are involved in learning a L2. One of them is intelligence, "a general academic or reasoning ability" (Ellis 1986). As Mc Donough (1981) suggests, intelligence refers to "the capacity rather than the contents of the mind." Initial attempts to identify successful and unsuccessful language learners focused mainly on the concept of intelligence (Gardner 1985). Intelligence is involved in the learning of other school subjects as well as an L2. It underlies "our ability to master and use a whole range of academic skills" (Ellis 1986).

\section{Introduction}

The concept of language aptitude has been developed to explain differences among individuals in language learning. It is considered to be a capacity specific to language learning rather than a general ability to learn, although there may be some indirect link between the two. Aptitude applies to both first and subsequent language learning. In foreign language learning, aptitude can be used as a means of predicting achievement.

Two sets of intellectual abilities are involved in learning an L2. One of them is intelligence, "a general academic or reasoning ability” (Ellis 1986). As Mc Donough (1981) suggests, intelligence refers to "the capacity rather than the contents of the mind." Initial attempts to identify successful and unsuccessful language learners focused mainly on the concept of intelligence (Gardner 1985). 
This was so because of the highly academic nature of language programmes and popularity of intelligence testing in psychology and education in those years.

Intelligence is involved in the learning of other school subjects as well as an L2. It underlies "our ability to master and use a whole range of academic skills" (Ellis 1986). Research has shown that intelligence is much more related to academic, formal aspects of L2 classroom learning (reading, grammar, vocabulary) than to communication aspects (listening comprehension, free oral production). Intelligence may be a powerful predictor in classroom SLA where formal teaching methods are used.

\section{Intelligence}

Two sets of intellectual abilities are involved in learning an L2. One of them is intelligence, "a general academic or reasoning ability" (Ellis 1986). As Mc Donough (1981) suggests, intelligence refers to "the capacity rather than the contents of the mind." Initial attempts to identify successful and unsuccessful language learners focused mainly on the concept of intelligence (Gardner 1985). This was so because of the highly academic nature of language programmes and popularity of intelligence testing in psychology and education in those years.

Intelligence is involved in the learning of other school subjects as well as an L2. It underlies "our ability to master and use a whole range of academic skills" (Ellis 1986). Research has shown that intelligence is much more related to academic, formal aspects of L2 classroom learning (reading, grammar, vocabulary) than to communication aspects (listening comprehension, free oral production). Intelligence may be a powerful predictor in classroom SLA where formal teaching methods are used.

The relationship between intelligence and second (or foreign) language learning is questionable (Mc Donough 1981). Because of the general nature of the concept of intelligence, it is difficult to see which school subject relies more heavily on it than any other. One would expect that all subjects are equally related to intelligence. The results of intelligence tests are conventionally quoted as "mental age" or "intelligence quotient" (IQ), which is usually found to have a reasonably useful power of predicting success in school subjects. Most intelligence tests are conducted through the medium of the first language and so, it is difficult to separate measured intelligence from the first language knowledge.

Intelligence does not appear to be an important factor in the first language acquisition. All children, except those who are severely mentally retarded, succeed in developing grammatical competence in 
their L1 (Lenneberg 1964 in Mc Donough 1981; Ellis 1986). If IQ is not strongly related to the development of the first language, then it has to be demonstrated that it is related to second language learning; it cannot be assumed. Mc Donough (1981) goes a step further in suggesting that intelligence "may not be related to language learning as such, but to the ability to profit from certain kinds of instruction." Despite these arguments, it is difficult to rule out effects of intelligence on SLA altogether. As Ellis (1986) notes, the effects of intelligence are limited to the rate and success of SLA but there is no evidence that it affects the route of acquisition.

\section{Aptitude}

The other set of intellectual abilities involved in learning an L2 is referred to as aptitude. It is hypothesized to be separate from intelligence. The concept of aptitude has been developed to account for the differences among learners in language learning and it is supposed to apply to both first and subsequent language learning (Byram 2000). Aptitude is not easy to define (Ellis 1986). If intelligence is "a general academic or reasoning ability", aptitude refers to "the specific ability a learner has, for learning a second language." It is "a stable and permanent ability" and may be innate or the product of previous learning experience (Wilkins 1974). Carroll (1981 in Skehan 1989) states that "foreign language aptitude is relatively fixed over long periods of an individual's life span, and relatively hard to modify in any significant way." Unlike learning strategies, aptitude is not amenable to training. The definition of aptitude refers to cognitive abilities rather than attitudes and affective dimensions of learning. Aptitude measures can predict achievement in cognitive language capacity rather than ability to communicate on an interpersonal level.

Research on language aptitude has been limited. Carroll and Sapon first developed Modern Language Aptitude Test in 1950s. They defined aptitude in terms of an individual's "phonemic coding ability" - the ability to identify distinct sounds and to retain and associate them with symbols, the sensitivity to grammatical structures, the ability to learn items of a foreign language by rote, and the ability to infer rules about a language from experience of the language. More recently, Skehan (1998) suggested that there are three components of aptitude: auditory ability (similar to "phonemic coding ability"); linguistic ability (combining Carroll's notions of grammatical sensitivity and ability to infer rules); and memory, to explain how students assimilate new material, how they store the memorized material in terms of patterns and generalizations and how they retrieve it from memory. 
Aptitude has been measured by standardized tests, such as the Modern Language Aptitude Test and the Language Aptitude Battery. Both these tests were developed in the United States by Carroll and Sapon (1959) and Pimsleur (1966) respectively. These tests were constructed to provide a reliable prediction of person's success in learning a language. They can be used to make a provisional selection of more promising from less promising students (Stern 1983).

What do the MLAT and the LAB measure? According to Carroll (1965, 1989), language aptitude comprises of four abilities - a) phonetic coding ability; b) grammatical sensitivity; c) inductive language learning ability; and d) memory ability. All aptitude tests are supposed to measure these abilities. Though similar in many ways, the MLAT (Carroll and Sapon 1959) and the LAB (Pimsleur 1966) do not measure exactly the same behaviours (Ellis 1986). The MLAT is for the use with people of 14 years and above. (The elementary form of the MLAT is intended for children between the ages of eight and eleven). The MLAT consists of five sub-tests: number learning, phonetic script, spelling clues, words in sentences, and paired associates. The first and the last sub-tests (number learning, and paired associates) measure associative memory; the secondphonetic script, measures phonetic coding ability; the third- spelling clues, native language vocabulary and phonetic coding ability; and the fourth- words in sentences, grammatical sensitivity.

The Language Aptitude Battery (Pimsleur 1966) has six sections. This test is appropriate for children aged 13 to 19. The first two sections of the LAB (grade point average and interest) depend on verbal reports. Pimsleur found that a school learner's average grades in all school subjects were often a good means of predicting how good he or she would be at language learning. So, he included a question on grades in his battery of tests for language aptitude (Littlewood 1984). In the first section, the grade point average, subjects are required to report their most recent yearend grades in English, Maths, Science and History (or Social Science); and in the second, Interest, the subjects declare their interest in the language through self-ratings on a five-point scale. Parts three to six in the LAB are - the vocabulary test, the language analysis test, sound discrimination test, and sound symbol test, respectively. The LAB has no grammatical test or its counter part and any effective coverage of memory. Pimsleur views motivation as an integral part of language aptitude and his LAB assesses subjects' interest in the language. On the other hand, Carroll and Sapon (1959) do not include a motivational component in the MLAT (Larsen-Freeman and Long 1991). 
The MLAT and the LAB reflect the audio-lingual principles of language teaching, which were prevalent in the fifties and sixties (Stern 1983; Ellis 1986). Little additional research on aptitude has been carried out after the construction of these batteries (Skehan 1989). However, the aptitude research is not without its problems. For example, it is not clear as to what cognitive processes are subsumed under the label of aptitude. One serious challenge levelled against the language aptitude tests is that they measure the abilities to learn sound and grammatical systems but do not specifically assess the subjects' ability to use sounds and structures to communicate meanings. Ellis (1986) suggests that the concept of aptitude may be widened to take into account communicative aspects of second language learning. The sub-tests of the language aptitude batteries are intended to tap different abilities that comprise language aptitude. But subjects may perform differently on individual sub-tests. It is possible that a learner scores highly on grammatical sensitivity test and performs poorly on phonetic coding ability but the LAB and the MLAT do not account for differential performance on individual aptitude sub-tests or components. In that case we may get different aptitude profiles, such as - an even-profiled learner, an analytic learner, and a memory based learner (Skehan 1989).

There is one more problem related to the aptitude research in SLA. It is not clear as to what extent intelligence and aptitude are separate concepts. Researchers like Oller and Perkins (1978) and Neufeld (1978 in Ellis 1986; and Larsen-Freeman and Long 1991) dispute the existence of a special aptitude for language acquisition. Krashen (1981) argues that aptitude is related to language 'learning' and not to language 'acquisition'. If the distinction between learning and acquisition is not sustained, Krashen's argument loses its force. Language processing is involved in both formal and informal language learning contexts. And therefore, aptitude can be relevant in both of these contexts. Oxford (1990 in Parry and Stansfield- eds.) states that language aptitude provides a cognitive foundation to second language learning and that individuals with high levels of aptitude "have good memories for speech sounds and form; and have well- developed reading skills."

\section{Conclusion}

Thus, the concept of language aptitude explains differences among individuals in language learning and a capacity specific to language learning rather than a general ability to learn, although there may be some indirect link between the two. Aptitude applies to both first and subsequent language learning. Two sets of intellectual abilities are involved in learning an L2. One of them is intelligence, "a general academic or reasoning ability" (Ellis 1986). As Mc Donough (1981) 
suggests, intelligence refers to "the capacity rather than the contents of the mind." This was so because of the highly academic nature of language programmes and popularity of intelligence testing in psychology and education in those years. Research has shown that intelligence is much more related to academic, formal aspects of L2 classroom learning (reading, grammar, vocabulary) than to communication aspects (listening comprehension, free oral production).

\section{References}

Ellis, Rod. Understanding Second Language Acquisition. $2^{\text {nd }}$ ed. Oxford: Oxford U P, 1986. Print.

Mc Donough, Steven H. Psychology in Foreign Language Teaching. $2^{\text {nd }}$ ed. London: ELBS/ George Allen and Unwin, 1981. Print.

Gardner, Robert C. Social Psychology and Second Language Learning: The Role of Attitudes and Motivation. London: Edward Arnold, 1985. Print.

Byram, Michael, ed. Routledge Encyclopedia of Language Teaching and Learning. London: Routledge (Taylor and Francis Group), 2000. Print. 
Towards Excellence: An Indexed Refereed Journal of Higher Education / Dr. Divyeshkumar Bhatt / Page 199$\underline{206}$

Wilkins, D. A. Linguistics in ///Language Teaching. London: Edward Arnold, 1974. Print.

Skehan, Peter. Individual Differences in Second Language Learning. London: Edward Arnold, 1989. Print.

Carroll, J.B. \& Sapon, P. The modern language aptitude test. Texas: Psychological Association. 1959. Print.

Stern, H. H. Fundamental Concepts of Language Teaching. Oxford: Oxford U P, 1983. Print.

Littlewood, W. T. Foreign and Second Language Learning: Language Acquisition Research and Its Implications for the Classroom. Cambridge: Cambridge U P, 1984. print.

Larsen-Freeman, Diane. "Second Language Acquisition Research: Staking out the Territory." TESOL Quarterly. Vol 25 No 2. 1991. 315-39. Print.

Neufeld, Gerald G. “Towards A Theory of Language Learning Ability.” Language Learning. Vol 29 No 2. 1979. 227-41. Print.

Krashen, Stephen. Principles and Practice in Second Language Acquisition. Oxford: Pergamon, 1982. Print.

Krashen, Stephen. Second Language Acquisition and Second Language Learning. Oxford: Pergamon Press, 1983. Print.

Oxford, Rebecca. "Styles, Strategies and Aptitude: Connections for Language Learning." Language Aptitude Reconsidered. Ed. Thomas. S. Parry and Charles. W. Stansfield. New Jersey: Englewood Cliffs, 1990. Print. 
Towards Excellence: An Indexed Refereed Journal of Higher Education / Dr. Divyeshkumar Bhatt / Page 199$\underline{206}$

Oxford, R. Styles, strategies, and aptitude: Connections for language learning. In T.S. Parry \& C.W. Stansfield (Eds.), Language Aptitude Reconsidered (pp. 67-125). Englewood Cliffs, NJ: Prentice Hall. 1990. Print.

\section{Hitendra Vyas}

S.V.Arts College, Ahmedabad, hitendrahvyas@gmail.com 